\title{
DisTORTED UNIVERSALITY - INTERNATIONALIZATION AND ITS IMPLICATIONS FOR THE EPISTEMOLOGICAL Foundations OF THE Discipline
}

\author{
WIEBKE KEIM
}

\begin{abstract}
In recent years, the articulation between the common core of the discipline and its local manifestations has become increasingly problematic. It might seem paradoxical that calls for more local sociologies appear at the very time of globalization. However, I argue that this double move - the internationalization of the scholarly community on the one hand and the localization of specific claims on the other - is not as ironic as it first appears. On the contrary, it has its foundations in the very history of the discipline, in the realities of its worldwide spreading, and in the forms of its international constitution that are marked by hierarchies and inequalities, especially with regard to South-North-relations.
\end{abstract}

Résumé. Récemment, l'articulation entre le corpus commun de la discipline d'un côté et ses manifestations locales de l'autre côté se trouve remise en question. Il peut paraître paradoxal que les revendications de sociologies plus «locales » émergent simultanément au processus de mondialisation. Toutefois, j’argumenterai que ce double mouvement vers l'internationalisation de la communauté scientifique d'un côté, et la localisation de ses réalisations spécifiques de l'autre côté, n'est pas aussi ironique que cela puisse paraitre à première vue. Au contraire, il semble que ces développements récents trouvent leur origine dans l'histoire même de la discipline, dans les réalités de son expansion globale et dans les formes de sa constitution internationale qui sont marquées par des hiérarchies et des inégalités profondes, surtout en ce qui concerne les relations Sud-Nord. 
It is a common observation today, that parts of the international community of scholars in sociology are developing far-reaching communication structures and extending their international contacts through organizational, associational, personal, and institutional networks. The International Sociological Association (ISA) is a major forum pushing for the internationalization of the discipline. ${ }^{1}$ The last World Congress of Sociology, held at Durban, South Africa, had a considerably higher participation rate of African scholars than any former world congress, suggesting that its networks are slowly integrating the southern intellectual communities. ${ }^{2}$ This distinguishes the current internationalization of the discipline from the inter-European and cross-Atlantic exchanges which have been present from the beginning of the discipline's history. ${ }^{3}$

This move towards increasing global interconnectedness in the scholarly arena accompanies the much debated globalization of society. These two developments are the origin of recent debates around the possible or factual globalization of sociology itself, motivating some to proclaim the need and possibility of "one sociology for one world" (Archer 1991). At the same time, there is resistance to this "one" and "truly global" sociology (see Adésínà 2002 for a direct, sharply critical response to Archer). At the opposite extreme, some fear a final fragmentation into localized, nationalized or "indigenized" sociologies. ${ }^{4}$

1. See Gingras (2002) for a discussion and empirical evidence on internationality in science; see Genov (1991) for institutional factors in the internationalization of sociology. For a differentiated definition of "internationalization" in sociology, see Smelser (1991:21-24).

2. The "global South" is here understood as a broad geographical and geopolitical category including mainly Africa, Asia, and Latin America. An operational definition is given by Shinn, Spaapen and Krishna (1997:28): "For analytical purposes we write about South and North as broad categories. We realize that by doing that we do not justice to the large socio-economic and cultural differences that exist between countries within these spheres. Moreover, it is arguably the case that some countries in the geographical South belong to the conceptual category of the North (Australia, New Zealand) and vice versa (some of the East European countries). Nevertheless, the above distinction between North and South is now broadly used."

3. However, the outcome of the ISA presidential elections in Durban show that the call for more geographical representation in the association has rather limited success when it comes to positions with decision-making power.

4. The term "indigenization" is here used in quotation marks to emphasize the valid criticism of some African scholars that any sociology is indigenous in its own context; the exclusive use of the term to refer to southern sociologies reinforces tendencies of exoticism: "It is, therefore, important to recognise what is idiographic about western sociology - regardless of the attempts to substitute it for global sociology. Insights rooted in other idiographic contexts cannot, therefore, be defined as indigenous sociology, or worse still, 'teaching sociology in the vernacular,' which has been the dominant 
Obviously, the articulation between the common core of the discipline and its local manifestations is becoming increasingly problematic (see Berthelot 1998). It might seem paradoxical that this call for more local or "indigenous" sociologies appears at the very time of globalization. However, I argue here that the double move of internationalization of the scholarly community on the one hand and the localization of specific claims on the other is not as ironic as it first appears. On the contrary, this development has its foundations in the history of the discipline, the realities of its worldwide spreading, and the forms of its international constitution.

\section{The International Constitution of Sociology: Inequalities, Stratification and The North-South Divide ${ }^{5}$}

Historically, sociology as a scholarly discipline within modern specialized institutions - as opposed to social thinking, which is probably as old as humankind and present all over the globe - emerged in Europe. Like the whole of the modern scientific system, it expanded through colonialism and imperialism, i.e. ,sociology in the global South originated as a subordinated, dependent, and exogenous sociology. After decolonization, structures of dependency often remained intact.

This historically subordinated integration into the discipline continues in the persisting centre-periphery-relations between the global South and the North-Atlantic sociologies. ${ }^{6}$ Two sets of factors account for this situation. At the extra-scientific level, lack of the necessary material infrastructure (Waast 2001; Bako 1994; 2002) and academic free-

response to attempts to infuse non-western discourses into global sociology" (Adésínà 2002:91). For a detailed critique of the indigenization debate, see Keim ( 2007).

5. The following is based on my doctoral research (Keim 2006) in which I give a series of empirical analyses, statistical as well as some qualitative indicators.

6. This is a macro perspective on the discipline. Elsewhere I develop the concept of counter-hegemonic currents to account for developments at smaller scales, i.e., integrated and locally connected scholarly communities that challenge North-Atlantic domination through their social scientific practice, and socially, as well as theoretically relevant scholarly production (see Keim 2008:167-194). For an empirical example of such counter-hegemonic currents, see my study on the development of South African labour studies (Keim 2008: 195-502). Furthermore, the specific status of scholars who can be defined as "hybrid individuals," i.e., those moving between several local communities, such as renowned representatives of postcolonial studies (Spivak, Said), falls out of the picture. In the empirical analyses of marginalization (Keim 2008), I pragmatically decided to categorize scholars according to their institutional affiliation rather than the colour of their skin or passport. This methodological pragmatism requires more detailed research to determine the scope and impact of these hybrid scholars on the local or national communities with whom they interact. 
dom (Diouf and Mamdami 1994) are often the main causes and do not require further explanation. ${ }^{7}$ However, there are numerous cases of welldeveloped sociologies - in terms of their infrastructural, institutional, and personal bases - that nevertheless do not gain any recognized international status (for Japan see Koyano 1976; Lie 1996). The reason seems to lie at the intra-scientific level, i.e., in the international constitution of the discipline, whereby southern sociologies remain marginalized from the core business of the discipline due to a variety of factors to be introduced briefly. ${ }^{8}$

An adequate indicator for marginalization - though not for scholarly production per se, as the conventional use of bibliometric indicators pretends - at the global level is the use of the so-called international databases (see Keim forthcoming). Analyses of the visibility of national sociological production in three such databases, the "Social Sciences Citation Index," "FRANCIS," and "Sociological Abstracts" reveal a highly polarized picture: US-American texts take the lion's share of publications, while the rest of the world is relegated to extremely limited visibility. Cross-checking with the alternative UNESCO-database, DARE, clearly shows that the low visibility of, for instance, African social science journals, does not reflect objective degrees of underdevelopment in the publication sector, but that major, well-established journals of the continent are ignored. None of them accounted for even $10 \%$ of the titles included in DARE. In the same vein, UNESCO data for book publication reveal that China is, worldwide, the first producer of social sciences literature, a reality not in any way reflected in any of the three indices. These databases thus prove to be not only an indicator of marginality, but also an instrument of marginalization.

Furthermore, unequal institutional relations are still a reality. African and Latin American sociologists get their PhDs in the prestigious

7. Recent examples from the African continent show that scientific development in terms of the building of material and institutional infrastructures and of a functioning, active scholarly community, is not a one-way endeavour. Long-term achievements can be reduced to almost nothing within a few years through destructive policies and under difficult economic conditions. For a general, empirical characterization of the situation in many African countries today, see Waast (2001) on a "free liberal market for scientific labour." For an account of the implementation of specific structural adjustment measures to one of the formerly most important higher education sectors of the continent - Nigeria - see Bako (1994; 2002). An extreme case of peripheral status due to material and political development problems is Palestinian sociology (Tamari 1994).

8. For detailed analyses and empirical evidence of the following, see Keim (2008:89-150; forthcoming). To allow for an isolation of tendencies of marginalization from effects of de facto scientific underdevelopment, I chose two examples of well-developed social science systems for my thesis: South African labour studies and Mexican migration studies. 
universities of Oxford, Cambridge, Sorbonne, or Harvard; make use of their libraries; and aspire to publication in British, French, or US-American journals. Even cooperation at the personal level is often marked by a deeply unequal division of labour. Thus, African social scientists complain that through so-called "cooperation programs," researchers from the North look for contacts only to gather the necessary local data for their own scholarly work; the conceptualization of the research, the evaluation, comparative analyses, interpretation, theory-building, and publication are done back in the North (see González Casanova 1968; Hountondji 1990a; 1990b; 1994; 2001/02; Sitas 2002).

Another feature inhibiting relationships on a more equal footing is the disciplinary structure of the social sciences, which channels discourses, personnel, and finances, keeping the southern social sciences away from the core of the discipline. Typically, ethnology/social anthropology and orientalism are the disciplines focused on studying societies outside of Europe, completed by "area studies" since the Cold War. An analysis of the activities of invited speakers at the "Ecole des Hautes Etudes en Sciences Sociales" (EHESS), one of the most prestigious French social science institutions in Paris, reveals that an invited African or Latin American sociologist usually ends up in the Department of African or Latin American Studies, where s/he relates to regional specialists, not to general social scientists. The same applies to publication: regionally specialized journals are more accessible to sociologists from the South than prestigious general sociological journals. Thus their contributions remain largely invisible to the northern and international sociological community.

These problems resulting from an unequal institutional division of labour already hint at another form of the North-South divide in the international constitution of sociology: the unequal cognitive division of labour, expressed aptly by McDaniel (2003:596): "Place matters only to those for whom Great Truths are not an option. The local is local for those without the power not to make it matter." As Alatas observed, there is a global division of labour between those who work on their own countries and those who work on countries other than their own, do comparative research, and arrive at considerably higher degrees of generalization. More often than not, the southern social sciences remain limited in scope and perspective; they focus on the local level, produce case studies applying theories produced elsewhere, or provide first-hand empirical data that may later feed into comparative and more generalizing work done in the centre of knowledge production (for empirical evidence, see Andrade Carreño 1998; Baber 2003; Keim 2008). In addition to that, a specific and particularly limiting form of locality is the pres- 
sure to define oneself as exotic, experienced by southern social scientists when confronting an international audience:

... there is a serious pressure to define ourselves as 'different' in the world context of ideas. Trying to be more than peripheral exotica in the 'global cultural bazaar' of social science we are bumping up against the niche trading tents we have been offered.... Of course we can be cynical and say that even here very few of us are considered good enough to be included, like Ali Farka Toure and Youssou N'Dour in the category called 'world music,' as decorative additions (Sitas 2002: 20).

Finally, marginality is related to evolutionist thinking in the social sciences which, despite postmodern deconstruction and disillusion, still prevails, creating hierarchies between objects of research and locations of sociological production. Although the bluntest versions of modernization theory - for instance, Rostow's model of "stages of economic growth" (1960) - are largely seen as obsolete today, the assumption that all regions and societies go through the same stages of development, with the rich nations of the North representing the peak of human development and the rest of the world "catching up," continues to affect the perception of social scientific production. Sociologists of supposedly backward societies are perceived and perceive themselves as unable to inform, in any meaningful way, but only able to learn from those of the "advanced societies." This was clearly expressed by a South African scholar in an interview: "... it is because they are the vanguard of development, they don't have anything to learn from us here. We can't inform them on the questions they are dealing with now" (Johann Marée, Interview 3.3.2004).

The problems outlined above lead to North-Atlantic domination within the international sociological community and within the discipline as a whole. The next section discusses how far these disciplinary, institutional, personal, and cognitive issues in the international constitution of sociology affect the epistemological foundations of the discipline.

\section{Implications for the Epistemological Foundations of Sociology: The Problem of Distorted Universality ${ }^{9}$}

Sociology, as the "science of society," from the beginning, has defined itself as a nomothetic discipline. This means that it pretends to produce

9. Several of the arguments outlined in this paragraph have aptly been dealt with in a recent publication by Connell (2006) who bases her critiques on detailed analysis of the works of three general theorists, namely Bourdieu, Giddens, and Coleman. 
generally valid, universal statements, concepts, and theories. However, I argue here that the North-Atlantic domination in sociology leads to a strongly distorted form of universality. Distorted, because the claim for universality so far has been formulated from a Eurocentric perspective. Many of the classical approaches thus formulate universalistic aspirations without reflecting their particular social location. It relies at the same time on radical exclusion and inclusion.

Radical exclusion refers to the fact that sociology, despite its self-understanding as "science of society," has always outsourced the study of the larger part of humanity and human societies to the regionally specialized disciplines. The so-called "general theory building," until recently, happened on a very reduced empirical basis, as Lander (2003:16-17, trans. W.K.) points out: "As the notion of universality was constructed on the basis of the particular (or parochial) experience of European history, and the totality of time and space of human experience was apprehended from that particular standpoint, a radically exclusive universality was created."

Furthermore, radical exclusion refers to the fact that the above mentioned structural, institutional, and disciplinary mechanisms of marginalization keep the sociological production of the South apart from the core business of the discipline. Gaillard (1987), among others, confirms that scholars of the southern countries share the widely held view that general theorizing is the most prestigious and valued endeavour within the disciplines. Related to this is the persisting cognitive division of labour and the evolutionist assumptions inherent in sociology, which affect the definition and perception of its object matter, reducing the time, space, and social experience of peripheral sociologies to the status of case studies. Due to their geographical and social localization, southern sociologies are seen as unable to make original contributions to general theory building.

At the same time, the historically developed Eurocentric universality is radically inclusive. General sociological theory, by definition, encompasses in the scope of its statements any society, North or South, and claims to be valid for all of them equally. The social realities of the southern hemisphere are thus always thought of as fitting into a universally valid scheme produced elsewhere. ${ }^{10}$ This tendency of radical

10. This criticism is not limited to activities in the North. S.H. Alatas (1974:695) conceptualized the problem as the "captive mind": "The habit of using general concepts such as 'modern,' 'achievement,' 'goals, ' 'planning' and so forth has given birth to a body of scholars' literature ... comparable to Diner's Club cards. They can be used everywhere. It is the preoccupation of the captive mind to indulge in the use of such imported concepts without a proper and meaningful linkage to the objective situation." 
inclusion blurs the distinction between the universal and the particular, equating the North-Atlantic particular with the universal. It is seen by Waldenfels as "the most dangerous form of Eurocentrism," the one that "hides behind the language of the Total" and thus "reduces any argument of the opponent to barely nothing" (Waldenfels 1997:88).

North-Atlantic domination thus exerts "tendencies of appropriation," to remain within Waldenfels' vocabulary. Epistemological Eurocentrism "miraculously encounters the particular Own in the General and the General in the particular Own." ${ }^{11}$ Excluding the majority of humankind with its social experience and its sociological reflections from sociology, while simultaneously including the "rest of the world" into general, universal theory, represents a fundamental epistemological problem for the discipline of sociology as a social science.

\section{Discourses of Resistance against North-Atlantic Domination and EUROCENTRIC UnIVERSALITY ...}

Recently, several attacks have been launched against North-Atlantic domination in the social sciences: critiques of Eurocentrism (Amin 1988; Fals-Borda and Mora-Osejo 2003), deconstruction of orientalism (Said 1978), attacks on anthropology and area studies (Mamdani 1997; Mafeje s.d.) to name only a few. Alatas (2001) conceptualizes how irrelevant imported approaches may be for the analysis and understanding of local societies, and propose necessary criteria to make southern sociologies more relevant to their own context. At the same time, the constructive approach of the indigenization project attempts to develop sociological concepts from social knowledge contained in oral poetry (Akiwowo 1986; 1999; Makinde 1988; Lawuyi and Taiwo 1990; Adésínà 2002).

African, Asian and Latin American sociologists, in many cases, seem to have assimilated the same vision, as Sitas (2002:11) points out: "The only way out for many southern sociologists is the quietism of borrowing from antinomical and critical concepts from discourses incubated in the Centre.... Without an alternative ground for thinking, these borrowings, however 'progressive' or 'critical,' consolidate a culture of application.... But a culture of 'application' turns the peripheral sociologist's 'space-time' particularity and locality into a 'case-study' and a variation within a 'same-ness.',

11. "Tendencies of appropriation are accompanied by specific centrisms: egocentrism, which insists on the individual Own; ethnocentrism, which insists on the collective Own; and logocentrism, which relies on a General that encompasses the Own and the Other ... in the last case, the particular Own and the Other are subsumed under a common General. The underlying specific form of Eurocentrism miraculously encounters the particular Own in the General and the General in the particular Own" (Waldenfels 1997:49). Translation W.K. 
But these reclamations from the global South haven't had a decisive impact on the hierarchical structures of the international social scientific community (for a critique of the indigenization debate, see Keim 2007). Furthermore, while these projects originated as political critiques, their attack on the very epistemological foundations of sociology has seldom been recognized as such (for an appropriate discussion of "contemporary epistemological challenges to the discipline of sociology," see Berthelot 1998. For a recent, valuable contribution to the debate, see Connell 2006).

These problems can be attributed to three causes. First of all, theoretical and deconstructive efforts as well as the indigenization project are limited to the level of theories and texts and do not take into account material inequalities or institutional and power factors. Second, these theoretical critics rely on the dominant "arena of competition" (Shinn 2000). ${ }^{12}$ The main idea underlying the concept of arena of competition is that marginalization in international sociology - i.e., the marginality of the Southern and the centrality of the North-Atlantic sociologies - is a problem of reciprocal recognition. This recognition happens in two steps. In the first step, everybody agrees on a common arena of competition: the mainstream international community with its platforms, its international journals, its prestigious institutions, etc. Only in a second step can the battle for recognition and prestige within this common arena of competition begin. The theoretical critiques thus rely on the dominant arena of competition, which they attack, to receive recognition and develop their critical potential. Third, the critical and deconstructive attacks emerged at a time when postmodern laissez-faire characterized large parts of sociological activities in the centre. This is especially true when it comes to unveiling scholarly discourse as a discourse of power. In that case, any effort for deconstruction is welcomed and the need to defend positions is no longer felt in the scholarly community. ${ }^{13}$

When these discourses of resistance against North-Atlantic domination were realized at all, they often were taken for political arguments.

12. Shinn, in his analysis of French science, talks about "arenas of diffusion" or "arenas of competition" referring to "traditional arena" on the one hand - specialized journals, scientific conferences etc. - and alternative arena like the "industrial arena of diffusion," i.e., the diffusion of scientific knowledge into industry (Shinn 2002). I adopt his concept of "arena," which allows for an appropriate distinction between orientations and priorities in social scientific production and communication at a local, regional, and international level; between scholars, non-academic actors, and audiences.

13. Considering the limited success of the deconstructive and critical projects, I propose elsewhere to draw attention to less explicit and rather practical forms of challenging North-Atlantic domination, in the form of what I conceptualize as "counter hegemonic currents," see footnote 6 . 
Indeed, in heated, and sometimes polemical, debates the refusal of hegemony, domination, hierarchies, and intellectual colonialism or dependency appears in the forefront of the discussion. The epistemological doubts contained in these criticisms regarding the project of a nomothetic discipline, i.e., of a social science claiming the ability to produce general, universal statements, are seldom acknowledged in the debate. Berthelot, in his article on contemporary epistemological challenges to sociology, one of which he sees in the up-coming localized claims within the scholarly communities of the South, seems to be one of the few who recognize the scope of the critique:

... it is the very epistemic project of sociology, its pretension to construct scientific knowledge - whichever is the criterion that defines this scientificity - that is questioned. It seems like hundred years after its birth as an autonomous scholarly discipline, sociology has become the object of a radical questioning of its project." (Berthelot 1998:2, trans. W.K.)

What is new about this debate - its spatial, topographical dimension - could at first sight be mistaken for, and reduced to, a new explosion of rationalism versus relativism, as Berthelot points out:

... most importantly, since the last decade, the articulation between national sociologies and the common corpus of the discipline ... has become a problematic link.... The postulate of universality of sociological theoretical models can be differently affected by the adopted position and the status attributed to the national location of sociology.... The political denunciation of hegemony might contain direct or indirect questionings regarding the very pretension of sociology to elaborate a universalisable discourse." (Berthelot 1998:2-3, trans. W.K.)

\section{... as a Consequence of the International Constitution of Sociology}

That this happens precisely in the famous "era of globalization" is not as surprising or paradoxical as it might appear at first sight. Those colleagues who are convinced of the possibility of a global, or globalized, and thus finally truly universal, sociology for one global, globalized world, may be irritated by such dissident voices (Archer 1991). But their ontological assumption has been radically rejected by sociologists from the global South, for reasons that Adésínà highlights:

This is precisely the problem. The 'unicity of humanity' that requires that we have 'a single discipline' for 'a single world' is in the imagination of 
the conventional western sociologist. It is one thing to defend foundationalism in sociology (at least some basis for epistemic adjudication) against the anarchist tendencies of postmodernism. It is an entirely different thing to assume that the dominant traditions in western sociology can pretend to speak for the global community of sociology. The nomothetic design that Archer saw in what she called 'the international endeavour with sociology' is one that has advanced not because of its universality but as an idiographic narrative of (a section of) the West, often part of the imperial agenda that has been called the 'triumph of the West.' The 'single humanity,' that Archer pitches for, assumes its 'unicity' by denying a voice to the non-western voices (and the non-dominant in the West, as well). (Adésínà 2002:94)

It appears that the tensions between local or national and general sociologies are a direct consequence of the growing international communication of the sociological community. Through increased international exchange and discussion and the slow, gradual accession of peripheral sociologists to central forums, scholars who saw themselves as practising universally valid sociology are confronted with the problem of North-Atlantic domination, formerly distorted as universality, as well as its consequences for sociological activity and production on the southern continents.

Quick, uncritical proclamations of an "internationalized," "global," or "globalized" sociology threaten to put a premature end to this discussion which is fundamental for the constitution of the discipline. In the foreword to a selection of articles from International Sociology, entitled Globalization, Knowledge and Society: Readings from International Sociology, Albrow (1990:6-7) proposes a sequencing of tendencies within sociology, from the universalism of the classics to the current globalization. The last phase, his model suggests, has already surpassed the former phase of "indigenization." Such assumptions are met by protests against new forms of "occidental hegemony," as Oommen (1991:81) argues:

However, even as Indian sociology is absorbing the relevant corpus of knowledge produced elsewhere, one fails to see any reciprocal response from other nations, continents, societies or civilizations. This is the Achilles heel of the ongoing process of internationalization of sociology.

Oommen sees the current state of internationalization or globalization as a reintroduction of North-Atlantic domination. He underlines his concern with a closer look at realities in Indian sociology. Here, as in other former colonies, the author sees a danger in premature attempts of internationalization, because the international exchange relationships 
are highly unequal. The reasons for these inequalities are, in his view, the underdevelopment of national sociological traditions and the generally unilateral flows of communication between previous colonies and Europe. He argues:

Therefore, the process will have to be initiated with great caution and circumspection. Let me list the main reasons for the advocacy of this cautious approach. First, internationalization, given the present predicament of sociology, would in effect mean the spread of Western sociology to non-Western countries.... Second, while Westernization is instantly recognized as a current which flows from the West, internationalization, although a camouflage for Westernization, passes on in a more respectable garb. This gives apparent autonomy to the non-West which is misleading. However, it is possible to transcend this misconception by recognizing that internationalization as it stands is essentially a Western construction.... Finally, internationalization to be authentic and fruitful should consciously design for a multidirectional flow of sociology, particularly strengthening the flow from the weak to strong centres. The project should not simply aim at 'educating' the non-Western but learning from them. (Oommen 1991:81-82).

\section{Theoretically Relevant Contributions from the Global South - SOME EXAMPLES}

An example of theoretically relevant contributions to the discipline emerging from the South is cepalism ${ }^{14}$ and its later development into dependency theory. These approaches led to the emancipation of the whole of the South American community from the international mainstream, introducing a paradigm shift away from the then dominant, rather Eurocentric modernization theory, Dependencia was later integrated into world systems theory (for a contextualization and evaluation of the importance of dependencia, see, among others, Andrade Carreño 1998; Briceño-León 2002; Lander 2003; 2004; Osorio 1994; Sonntag 1989). It is noteworthy that the formation of this current did not start as a purely theoretical argument. On the contrary, it was very much grounded in local concerns for the developmental problems of the region after the Second World War that were of major importance to economists, political leaders, and social scientists alike. The connection to extra-academic actors and the implementation of social scientific results through eco-

14. "Cepalismo," was a theoretical current named for the institution from which it emerged: CEPAL, "Comisión Económica para América Latina," a UN think tank established in 1948, with its headquarters in Santiago de Chile. 
nomic and developmental policies was, in some cases, even embodied in the personalities of intellectuals at the forefront of the debate, who were protagonists in both fields (for example, the first authors of the programmatic text in the domain, Cardoso and Faletto 1978 [1969]).

The same is true of two recent publications emerging out of South African labour studies. This research community developed in continuous contact and debate with the nonacademic protagonists of the antiapartheid movement and later on the transition and reconstruction process, which started with the labour movement. Out of this active local community, von Holdt (2003) published a remarkable book, that combines in-depth empirical analysis in the form of a workplace ethnography of a steelwork near Johannesburg, with far-reaching theoretical conclusions that should feed into labour studies literature at large as well as into transition theory. The author, himself engaged in labour support activities, former editor-in-chief of the popular journal South African Labour Bulletin, which gave him access and insights into the worlds of work and workers, is today a researcher at the national trade union confederation's research institute NALEDI (National Labour and Development Institute). Transition from Below (Holdt 2003) makes a fundamental contribution to transition theory, which was initially developed with regard to the transition processes taking place in Eastern Europe and from there transposed and applied, among others, to the South African case. Von Holdt, however, challenges the conventional view of a double transition - economically, from a closed economy to liberalization; politically, from authoritarianism to democracy - adding a third dimension - the sociocultural transition from colonial to postcolonial society. This modification may be of relevance to historical or contemporary transition processes in other countries of the global South, especially other former settler colonies, and ought to gain appropriate recognition internationally.

Another representative of the South African community recently produced a book in general sociology (Sitas 2004). The publication can be seen as a continuation of the earlier indigenization debate, but goes beyond it at several levels. Methodologically, Sitas uses oral texts - reworked in the form of "theoretical parables" - as a basis, giving them a "theoretical plus value." This methodological choice arises out of his personal experience as a university-based intellectual involved in community activities that encouraged him to reduce the distance between academic and non-academic discourses:

I argue, instead, that the fence between the citadel of knowledge and science and the fields needs cutting. The problem contexts of the questions 
we need to answer will have to be a negotiation with the Mshengu, the Shelelembuzes and others, learning is everywhere and theorising too. [The parables' project] asks of knowledge and reliability to be peoplecentred, generously abstract and contextually moral. (Sitas 2004:69)

The parables project's aim is to produce sociological knowledge through the parables and discussions of these short texts in and outside of academia. The author, in his own interpretations and theorizations of the parables, takes up basic sociological assumptions, discusses and criticizes different theoretical approaches, and proposes alternative concepts. At the centre of the debate are the realities of a modernity that did not result from the transition from feudalism to capitalism, but from colonialism.

A central issue in the parables is that modern institutions - factory, prison, university - have disciplinary power over people. The actors' navigation systems, their cognitive capacities, language, and forms of interaction can collapse, as in the case of this young woman who migrated from her rural home to the city:

The girlwoman [in one parable] experiences disoralia - an inability to establish parameters for meaningful communicative practice; disvaluation and degendering - she is not only a notwoman she is a new thing. She had already been told that the curse of her line was to visit her. In transgressing values and norms, in following the sounds of the letters [of her lover], she is leaving a significant value system. (Sitas 2004:90)

This can lead to disoriented, traumatized, mad behaviour. Nevertheless, Sitas and the parables show that there is always some degree of dissonance; an asymmetry; a resistance to institutions, structures, and systems in the agency and subjectivity of individuals and communities. Considering the hardship and efforts the humans in the parables undergo to face institutional pressures, the postmodern assumption of a decentred subject, according to the author, appears to be a "privileged piece of superficiality":

Such a conception confuses roles, strategies and behaviour with the struggle to 'centre' our navigating mechanisms, to steer through a maze of pressures and processes. The active, refracting and recoiling agency ... must not be confused with the autonomous subject of bourgeois enlightenment, but ... when it 'gives in,' the result is fragmentation, a dispersal into meaninglessness and de-rangement, infraction (Sitas 2004:102).

The author leads a similar theoretical discussion that challenges the current canon of the discipline on the relation between power, freedom, 
and the social conditions of emancipation in contexts where an ideal communication community, in the sense of Habermas, does not exist, and where the mere possibility of verbally expressing discontent is already an achievement.

The parables project challenges a series of sociological assumptions taken for granted in the established literature. Indeed, the status of the parables itself is disturbing. They are not the "authentic" pieces of social reality that we usually expect from far-away countries and expose in ethnographic collections. The parables are an experimental and theoretical elaboration of social knowledge in narrative form. Didactically, they are meant to encourage intellectual discussion. They form part of the process of knowledge generation, but also of social reality, containing symbolic capital for future actions. They do not establish the one truth as conventional parables do, but contain diverse analytical consequences. The parables project, in a very experimental way, brings together activities and functions that we usually separate. At the same time, this strategy reduces the distance between sociology and its object. Its separation from the "pre-notions" on which sociologists have relied since Comte and Durkheim, does not point to power relations between the researcher and his "object," but enhances a common process of reflection. This is, in part, motivated by the author's experience as an engaged intellectual:

We have been convinced that the 'researched' is different from a piece of chalk... The 'researched' talked back, argued, resisted the classifications and pointed out that the researcher, professor sir or madam, was also part of the field.... (Sitas 2004:41)

Sitas (2004:23) engages with classical and postmodern theory, criticizes them alike and confronts them with a sociology, that aims at being "neither premodern, modern, nor postmodern," "universally comprehensible but arrogantly local" and "communally accessible."

It remains to be seen how far these challenging contributions will penetrate to the core of the discipline and be able to deploy their potentials. The mentioned examples should encourage the international community to realize, at least, that the on-going marginalization tendencies, which the South African authors were inclined to confirm in a series of interviews, have strongly counterproductive and limiting effects on the development of the discipline as a whole.

In this regard, it is important to note that the majority of critics of North-Atlantic domination, as well as the proponents of alternative approaches in the global South, question the international constitution of sociology at the present stage, rather than the general possibility of sociology as a social science. However, in order to make this possibil- 
ity a reality, a lot remains to be done. As long as structural and political problems in the international scholarly community (i.e., developmental problems in the South, as well as personal, institutional, disciplinary and cognitive mechanisms of hierarchy and marginalization), are not addressed and resolved, a meaningful discussion on equal terms around globalization and a claim for universality in sociology can not be thought of. It is certainly in this sense that Burawoy's idea of a "reconfiguration" of the global social scientific division of labour is to be understood within the framework of his project to "provincialize the social sciences" (Burawoy 2005:16).

Apart from decisive structural and institutional shortcomings and distortions of the discipline, each researcher must question perceptions of colleagues, scholarly communities, and their production here and there, to achieve a more inclusive view of sociology that allows for a variety of voices and viewpoints. Current endeavours in the area of theories of modernity, with emerging concepts such as "multiple modernities" and with huge projects of global communication on a more equal footing might be a further step in the right direction.

\section{REFERENCES}

Adésínà, Jìmí. 2002. Sociology and Yoruba studies: Epistemic intervention or doing sociology in the 'vernacular'? African Sociological Review 6(1):91-114.

Akiwowo, Akinsola A. 1986. Contributions to the sociology of knowledge from an African oral poetry. Pp. 103-117 in Martin Albrow and Elizabeth King, eds., Globalization, Knowledge and Society: Readings from International Sociology. London: Sage Publications.

1999. Indigenous sociologies - extending the scope of the argument. International Sociology 14(2):115-138.

Alatas, Syed Farid. 2001. The study of the social sciences in developing countries: Towards an adequate conceptualisation of relevance. Current Sociology 49(2):1-27.

Alatas, Syed Hussein. 1974. The captive mind and creative development. International Social Science Journal 24(4):691-700.

Albrow, Martin. 1990. Introduction. Pp. 3-13 in Martin and Elizabeth King, eds., Globalization, Knowledge and Society: Readings from International Sociology. London: Sage Publications.

Amin, Samir. 1988. L'eurocentrisme. Paris: Anthropos.

Andrade Carreño, Alfredo. 1998. La sociología en México: temas, campos científicos y tradición disciplinaria. México: Universidad Nacional Autónoma de México. 
Archer, Margaret. 1991. Sociology for one world: Unity and diversity. International Sociology 6(2):131-147.

Baber, Zaheer. 2003. Provincial universalism: The landscape of knowledge production in an era of globalization. Current Sociology 51(6):615-623.

Bako, Sabo. 1994. Education et ajustement en Afrique: Conditionnalités et résistance. Pp. 171-201 in Mamadou Diouf and Mahmood Mamdani, eds., Liberté académique en Afrique. Dakar: Council for the Development of Social Science Research in Africa.

2002 Union, state and the crisis of higher education: The latest phase of struggle for and against restructuring and deregulating the Nigerian universities. Paper prepared for the $10^{\text {th }}$ CODESRIA General Assembly in Kampala, Uganda, 8-12 December. http://codesria.org/Links/Ho...\%20 GA\%2012-20/Education Bako.htm (Accessed January 2005).

Berthelot, Jean-Michel. 1998. Les nouveaux défis épistémologiques de la sociologie. Sociologie et Sociétés 30(1):1-16.

Briceño-León, Roberto. 2002. Introduction: Latin America - a challenge for sociology. Current Sociology 50(1):9-18.

Burawoy, Michael. 2005. Provincializing the social sciences. Pp. 508-525 in George Steinmetz, ed., The Politics of Method in the Human Sciences. Durham, NC: Duke University Press. http://sociology.berkeley.edu/faculty/burawoy/workingpapers.htm (Accessed March 2006).

Cardoso, Fernando Henrique and Enzo Faletto. 1978 [1969]. Dépendance et Développement en Amérique latine. Paris: PUF.

Connell, Raewyn. 2006. Northern theory: The political geography of general social theory. Theory and Society 35(2):237-264.

Diouf, Mamadou and Mahmood Mamdani, eds. 1994. Liberté académique en Afrique. Dakar: Council for the Development of Social Science Research in Africa.

Fals-Borda, Orlando and Luis E. Mora-Osejo. 2003. Context and diffusion of knowledge - a critique of Eurocentrism. Action Research 1(1):29-37.

Gaillard, Jacques. 1987. Les chercheurs des pays en développement - origines, formations, et pratiques de la recherche. Mémoire de DEA au Conservatoire National des Arts et Métiers 1986. Thesis.

Genov, Nikolai. 1991. Internationalization of sociology: The unfinished agenda. Current Sociology 39(1):1-20.

Gingras, Yves. 2002. Les formes spécifiques de l'internationalité du champ scientifique. Actes de la Recherche en Sciences Sociales 141-142: 31-45.

González Casanova, Pablo. 1968. Las ciencias sociales. Pp. 1-44 in Pablo González Casanova and Guillermo Bonfil, eds., Las ciencias sociales y la antropología - dos ensayos. México: Ediciones Productividad. 
Holdt, Karl von. 2003. Transition from Below: Forging Trade Unionism and Workplace Change in South Africa. Pietermaritzburg: University of Natal Press.

Hountondji, Paulin. 1990a. Recherche et extraversion: éléments pour une sociologie de la science dans les pays de la périphérie. (Research and extraversion: Elements for a sociology of science for the countries of the periphery). Africa Development 25(3/4):149-158.

1990b. Scientific dependence in Africa today. Research in African Literatures 21(3):5-15.

1994. Démarginaliser (Demarginalize). Pp. 1-37 in Paulin Hountondji, ed., Les savoirs endogènes (Endogenous knowledge). Dakar: Codesria. 2001-02 Le savoir mondialisé: déséquilibres et enjeux actuels (Globalized knowledge: Imbalances and actual challenges). Conference on "La mondialisation vue d'Afrique" (Globalization from an African perspective) at the University of Nantes/Maison des Sciences de l'Homme Guépin. www.msh-alpes.prd.fr/guepin/afrique/charpar/cfpaulin.pdf (Accessed Oct. 2003)

Keim, Wiebke. 2006. Vermessene Disziplin. Nordatlantische Dominanz und konterhegemoniale Strömungen in der Entwicklung afrikanischer und lateinamerikanischer Soziologien (North-Atlantic domination and counterhegemonic currents in the development of African and Latin American sociologies) PhD Thesis, University of Freiburg and Paris IV-Sorbonne. 2007. Jenseits von Afrika - Auseinandersetzungen um den Hegemonialanspruch der 'Internationalen Soziologie.' (Out of Africa: Discussions on hegemonic tendencies in 'International Sociology') Pp. 121-139 in Sabine Ammon, et al., Wissen in Bewegung - Vielfalt und Hegemonie in der Wissensgesellschaft (Knowledge in Movement: Diversity and Hegemony in the Knowledge Society). Göttingen: Velbrück.

2008. Vermessene Disziplin. Zum konterhegemonialen Potential afrikanischer und lateinamerikanischer Soziologien. Bielefeld: Transcript.

forthcoming. Social sciences internationally: The problem of marginalization and its consequences for the discipline of sociology. Submitted for publication to African Sociological Review.

Koyano, Shogo. 1976. Sociological studies in Japan: Pre-war, post-war and contemporary stages. Current Sociology 24(1): 7-79.

Lander, Edgardo. 2003, ed. La colonialidad del saber: eurocentrismo y ciencias sociales - perspectivas latinoamericanas. Buenos Aires: Consejo Latinamericano de Ciencias Sociales.

2004 Universidad y producción de conocimiento: reflexiones sobre la colonialidad del saber en América Latina. Pp. 167-179 in Irene Sánchez Ramos and Raquel Sosa Elízaga, eds., América Latina: los desafíos del pensamiento crítico. México: Siglo Veintiuno Editores.

Lawuyi, O.B. and Olufemi Taiwo. 1990. Towards an African sociological tradition: A rejoinder to Akiwowo and Makinde. Pp. 135-151 in Martin Albrow and Elizabeth King, eds., Globalization, Knowledge and Society: Readings from International Sociology. London: Sage Publications. 
Lie, John. 1996. Sociology of contemporary Japan. Current Sociology 44(1):166

Mafeje, Archie. s.d. Anthropology in post-independence Africa: end of an era and the problem of self-definition. Multiversity of the MultiWorld Network, Malaysia http://www.multiworld.org/m_versity/articles/article. htm (Accessed September 2005).

Makinde, A. Akin. 1988. Asuwada principle: An analysis of Akiwowo's contributions to the sociology of knowledge from an African perspective. Pp. 119-134 in Martin Albrow and Elizabeth King, eds., Globalization, Knowledge and Society: Readings from International Sociology. London: Sage Publications.

Mamdani, Mahmood. 1997. Africa and 'African Studies'. Pp. 149-154 in Nico Cloete, et al., eds., Knowledge, Identity and Curriculum Transformation in Africa. Cape Town: Maskew Miller Longman.

McDaniel, Susan A. 2003. Introduction: The currents of sociology internationally: Preponderance, diversity and division of labour. Current Sociology 51(6):593-597.

Oommen, T.K. 1991. Internationalization of sociology: A view from developing countries. Current Sociology 39(1):67-84.

Osorio, Jaime. 1994. La sociología latinoamericana: tendencias y perspectivas. Pp. 297-305 in Leal y Fernández, Juan Felipe et al., eds., La sociología contemporánea en México: perspectivas disciplinarias y nuevos desafíos. México: Universidad Nacional Autónoma de México.

Rostow, Walt W. 1960. The Stages of Economic Growth: A Non-communist Manifesto. Cambridge: Cambridge University Press.

Said, Edward W. 1978. Orientalism. New York: Pantheon Books.

Shinn, Terry. 2000. Axes thématiques et marchés de diffusion. La science en France, 1975-1999. (Thematic axes and diffusion markets: Science in France, 1975-1999) Sociologie et Société 32(1):43-69.

Shinn, Terry, Jack Spaapen, and Venni Krishna, eds. 1997. Science and Technology in a Developing World. Sociology of Sciences Year Book. Dordrecht: Kluwer Academic Publishers.

Sitas, Ari. 2002. The African Renaissance Challenge and Sociological Reclamations in the South, Durban. http://gsp.soziologie.uni-freiburg.de/gspdat/ people/sitas/seminar-freiburg-2002/african-renaissance.pdf. (Accessed October 2005) 2004. Voices that Reason: Theoretical Parables. Pretoria: Brill Academic.

Smelser, Neil J. 1991. Problematics in the internationalization of social science knowledge. Current Sociology 39(1):21-46.

Sonntag, Heinz R. 1989. Duda, certeza, crisis - la evolución de las ciencias sociales de América Latina. Caracas: Nueva Sociedad. 
Tamari, Salim. 1994. Problems of social science research in Palestine: An overview. Current Sociology 42(2):67-86.

Valencia Valencia, Enrique. 1994. La teoría social latinoamericana: tradición intelectual y problema actuales. Pp. 317-323 in Leal y Fernández, Juan Felipe et al., eds., La sociología contemporánea en México: perspectivas disciplinarias y nuevos desafíos. México: Universidad Nacional Autónoma de México.

Waast, Roland. 2001. Afrique, vers un libre marché du travail scientifique? (Africa, towards a free market of scientific labour?) Economies et Sociétés Série F, 39(9-10):1361-1413.

Waldenfels, Bernhard. 1997. Topographie des Fremden. Frankfurt/Main: Suhrkamp.

Wiebke Keim completed a PhD in Sociology at the Universities of Freiburg/ Germany and Paris IV-Sorbonne/France. Her focus areas are history and epistemology of the social sciences, African and Latin American sociological traditions, sociology of science and knowledge, globalization, precarity and social inequality. She spent three months as a postdoc at the University of KwaZuluNatal in Durban/South Africa. She is currently affiliated to the Chair for Social Policy and Social Work at University of Fribourg/Switzerland. She is a research associate at Industrial, Organisational and Labour Studies Research, University of KwaZuluNatal and has teaching commitments at the Universities of Bern/ Switzerland and Freiburg/Germany. 